\title{
Utilization of HVS Paper Waste for The Manufacture of Oxalic Acid
}

\author{
Agung Subyakto ${ }^{1 *}$, Fiqrotul Wasiyah ${ }^{1}$, Linaniyyatul Masruroh ${ }^{1}$
}

\begin{abstract}
The purpose of this research is to determine the effect of time and temperature on the manufacture of oxalic acid from HVS paper waste by removing ink and alkali melting methods This research follows two steps i.e., pre-treatment and then paper hydrolysis. It was found that the average temperature that produces the most oxalic acid is at 80 min and $65^{\circ} \mathrm{C}$, which is $3.9 \mathrm{~g}$. The analysis results show that the melting point obtained is between $100-101{ }^{\circ} \mathrm{C}$. This corresponds to the actual melting point of oxalic acid based on the Indonesian National Standard (SNI) approximately $101-102^{\circ} \mathrm{C}$.
\end{abstract}

Keywords-HVS, Hydrolysis, NaOH, Oxalic Acid, Waste

\section{INTRODUCTION}

HVS paper waste in Indonesia has increased by $50 \%$ every year. The high amount of HVS paper waste is happened due to the production of HVS paper that is not comparable to the processing of waste generated from the use of HVS paper. This can be seen from the estimated paper production which reached 13.7 million tons per year without increasing paper recycling [1].

The use of paper that increases every year causes a worse impact on the environment, namely the accumulation of used paper, which is still seen as useless environmental waste. It has the potential to negatively impact the environment and global warming, which can continue to increase due to smoke produced from burning paper waste. Therefore, further processing is needed to reduce the amount of HVS paper waste and increase the use-value.

Paper is made from various types of plants containing lots of cellulose, shown in Table 1. Paper is a material that contains high cellulose because the paper is made of wood. Amylum or cellulose is formed by combining glucose molecules that form straight or branched chains by releasing water [2].

Table 1.

CHEMICAL COMPOSITION OF USED HVS PAPER SUBSTRATE

\begin{tabular}{ll}
\hline \hline Chemical Composition & Amount (\%) \\
\hline Lignin & 5 \\
Hemicellulose & 8 \\
Cellulose & 85 \\
Ash Compound & 2 \\
\hline \hline
\end{tabular}

Paper generally contains more than $90 \%$ cellulose content. Lignocellulose is a term commonly used to refer to a material containing $5 \%$ of lignin, $85 \%$ of cellulose, $8 \%$ of hemicellulose, and $2 \%$ of other components [3]. With a high enough cellulose content, HVS paper waste can be processed into oxalic acid. Oxalic acid is a dicarboxylic compound in which the $\mathrm{C}$ atom, each, binds one hydroxyl group.
Oxalic acid has a pyramid rhombic crystalline form, is colorless and transparent, odorless and hygroscopic. Oxalic acid is easily entirely oxidized by the influence of high heat so that it breaks down into $\mathrm{CO}_{2}$ and formic acid. The manufacture of oxalic acid-containing cellulose uses several steps such as hydrolysis, filtration, precipitation with $\mathrm{CaCl}_{2}$, acidification with $\mathrm{H} 2 \mathrm{SO} 4$ and crystallization. In using alkaline solutions as hydrolysis solutions, the effective alkalis used are strong alkalis, for example $\mathrm{NaOH}$ and $\mathrm{Ca}(\mathrm{OH})_{2}$, because strong alkalis are more effectively used in the manufacture of oxalic acid. The reaction with strong alkalis is called alkaline catalyzed hydrolysis [4]

Factors that influence the manufacture of oxalic acid are temperature and time. If the temperature is high, the constant speed of the reaction is faster, but if it has exceeded the optimum temperature, the yield of oxalic acid will be reduced due to the presence of glucose which breaks into charcoal. Meanwhile, the long melting time will increase the chance of the reagents in contact and result in relatively large amounts of oxalic acid. However, too long cooking time will cause the yield of oxalic acid to decrease due to further reactions [5].

The difference between this study and previous studies is that this study uses a pre-treatment process that uses removing ink and lignin [6]. This research aimed to determine the effect of time and temperature on the manufacture of oxalic acid from HVS paper waste by removing ink and alkali melting methods.

\section{METHOD}

\section{Material}

HVS Paper Waste (HVS paper waste can be found at flea markets or offices), Aluminium Foil, Aquadest (H2O), Sulfuric Acid (H2SO4) 4N 96\% P.A, Ethanol (C2H6O) 96\% P.A., Hidrogen Peroxide (H2O2) 65\%, Gauze, Kalium Permanganate (KMnO4) 0,1 N 50\%, Calcium Chloride $(\mathrm{CaCl} 2)$ 10\%, Whatman Filter Paper, Paraffin Oil, Sodium Hydroxide (NaOH) 40\% (Chemicals can be found in chemical stores).

\footnotetext{
${ }^{1}$ Department of Industrial Chemical Engineering, Institut Teknologi Sepuluh Nopember, Kampus ITS, Sukolilo, Surabaya 60111, Indonesia. Email: glu_chem@chem-eng.its.ac.id
} 


\section{Research Stage}

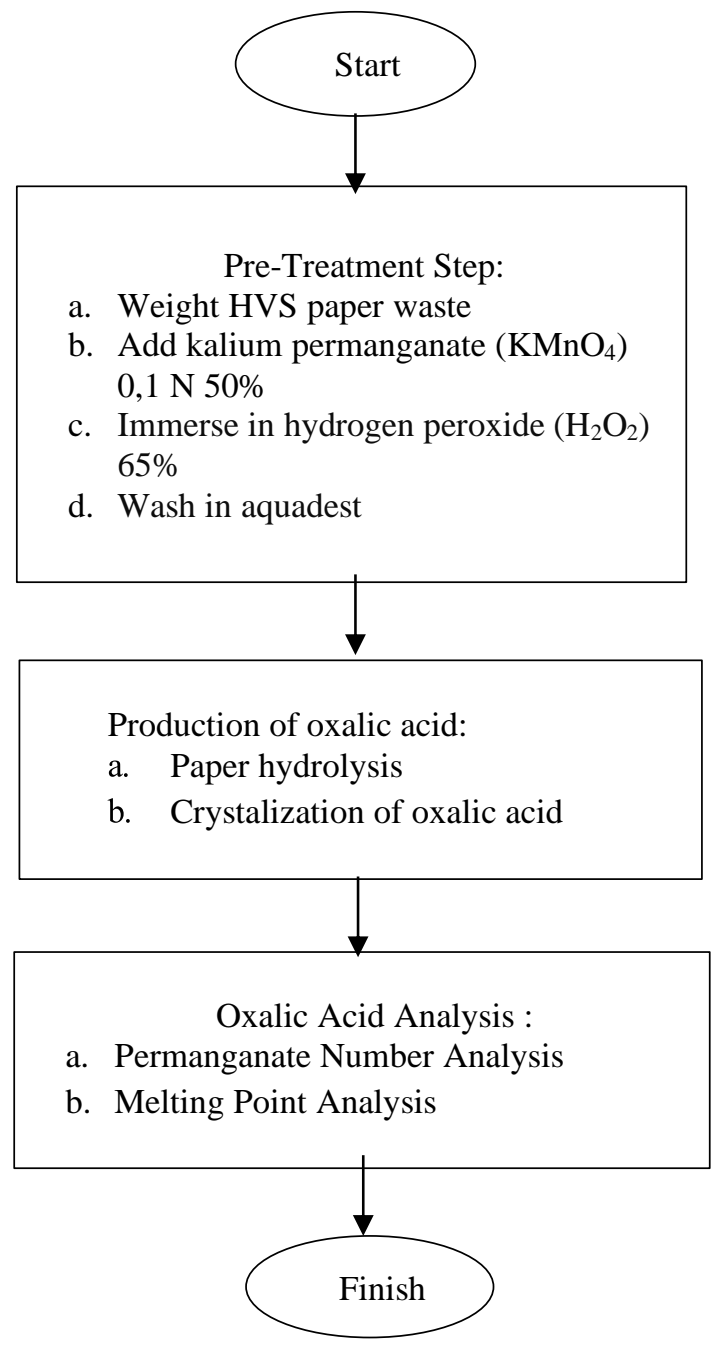

\section{Pre-Treatment Stage}

Weigh the HVS paper waste to $600 \mathrm{~g}$. Add $0,1 \mathrm{~N}$ kalium permanganate $\left(\mathrm{KmnO}_{4}\right) 50 \%$ solution to the paper waste then stir it. It can increase oxalic acid yield to $2 \%$. Then immerse the paper waste in hydrogen peroxide $\left(\mathrm{H}_{2} \mathrm{O}_{2}\right)$ $65 \%$, it can increase the yield to $8 \%$. And the last, rinse with aquadest. It can increase the yield of result to $10 \%$.

\section{Oxalic acid production}

For stoichiometry calculation can used SIAB application, the application to be carried out aims to develop android-based learning media on acid-base stoichiometry materials. This application just focuses on acid base stoichiometry [7].

\section{Paper Hydrolysis}

After pre-treatment process, enter paper from the previous pre-treatment into three-neck flask then add $40 \% \mathrm{NaOH}$ solution :

$$
\left(\mathrm{C}_{6} \mathrm{H}_{10} \mathrm{O}_{5}\right) \mathrm{n}+2 \mathrm{NaOH} \longrightarrow \mathrm{Na}_{2} \mathrm{C}_{2} \mathrm{O}_{4}+\mathrm{C}_{4} \mathrm{O}_{3} \mathrm{H}_{12}
$$

Then the instrument is paired and adjusted the time and temperature used. Time used is $60 \mathrm{~min}$ on each several temperatures that is $55^{\circ} \mathrm{C}, 65^{\circ} \mathrm{C}, 75^{\circ} \mathrm{C}$ dan $95^{\circ} \mathrm{C}$, the three-neck flask is set on and heated. After heating the solution has to be cooled, and the filtrate is filtrated using filtrate paper to Erlenmeyer glass, the filtrate then will be rinsed with hot aquadest to other Erlenmeyer till $400 \mathrm{~mL}$.
This procedure needs to be repeated for other time variables $(70,80 \mathrm{dan} 90 \mathrm{~min})$ on its $55^{\circ} \mathrm{C}, 65^{\circ} \mathrm{C}, 75^{\circ} \mathrm{C}$ dan $95^{\circ} \mathrm{C}$.

\section{Crystallization of Oxalic Acid}

Crystallization of oxalic acid consists of three-step:

- A supersaturated state is a condition when the solution exceeds its saturated point.

- Nucleation state is a state of core crystal-forming from the supersaturated solution

- Growth is the further development of crystal molecules from nucleation state into their equilibrium state

From the explanation above, below is the step method for oxalic acid crystallization :

1. Move the obtained hydrolysis filtrate by using a pipette to Erlenmeyer, then add $\mathrm{CaCl}_{2} 10 \%$

$$
\mathrm{Na}_{2} \mathrm{C}_{2} \mathrm{O}_{4}+\mathrm{CaCl}_{2} \longrightarrow \mathrm{CaC}_{2} \mathrm{O}_{4}+2 \mathrm{NaCl}
$$

2. Then add $\mathrm{H}_{2} \mathrm{SO}_{4} 96 \%$ to the filtrate

$$
\mathrm{Na}_{2} \mathrm{C}_{2} \mathrm{O}_{4}+\mathrm{H}_{2} \mathrm{SO}_{4} \longrightarrow \mathrm{H}_{2} \mathrm{C}_{2} \mathrm{O}_{4}+\mathrm{Na}_{2} \mathrm{SO}_{4}
$$

3. Then filter the filtrate and add $100 \mathrm{~mL} \mathrm{H}_{2} \mathrm{SO}_{4} 4 \mathrm{~N}$

$$
\mathrm{CaC}_{2} \mathrm{O}_{4}+\mathrm{H}_{2} \mathrm{SO}_{4} \longrightarrow \mathrm{H}_{2} \mathrm{C}_{2} \mathrm{O}_{4}+\mathrm{CaSO}_{4}
$$

4. After all of the reactions, oxalic acid and calcium sulphate formed; then the filtrate is filtrated and washed using ethanol $\left(\mathrm{C}_{5} \mathrm{H}_{6} \mathrm{O}\right) 96 \%$. The crystal of oxalic acid formed due to the supersaturated condition; it occurs because the solvent (ethanol) can not dissolve oxalic acid again in the solution and it forced the crystal to be formed by reducing its solvent be done cooling or evaporation.

Ethanol $\left(\mathrm{C}_{5} \mathrm{H}_{6} \mathrm{O}\right) 96 \% \times \mathrm{ml}$ :

$$
2 \mathrm{H}^{+}{ }_{(\mathrm{g})}+\mathrm{SO}_{4}{ }^{2-}{ }_{(\mathrm{g})} \longrightarrow \mathrm{H}_{2} \mathrm{SO}_{4(\mathrm{l})}
$$

Then filtrate is heated to $70^{\circ} \mathrm{C}$. in this process, the filtrate will be in supersaturated condition and the nucleation step is initiated in that supersaturated solution. After that, the filtrate is cooled with ice for approximately 24 hours until the crystal is formed. This phase is called the growth phase until it reach an equilibrium state.

\section{Mass calculation of oxalic acid (gr)}

Crystal mass $=($ filter paper + crystal $)-$ blank paper

- Weigh oxalic acid $\left(\mathrm{H}_{2} \mathrm{C}_{2} \mathrm{O}_{4}\right)$ as $\mathrm{xg}$

- Add aquadest as $\mathrm{x} \mathrm{mL}$ and enter it to erlenymer $\mathrm{x} \mathrm{mL}$, then add $\mathrm{H}_{2} \mathrm{SO}_{4} 4 \mathrm{~N}$ as $\mathrm{mL}$

- Then the $\underset{\text { solution }}{2 \mathrm{H}^{+}(\mathrm{g})+\mathrm{SO}_{4}^{2-}} \underset{\mathrm{g})}{\longrightarrow} \mathrm{H}_{2} \mathrm{SO}_{4(\mathrm{l})}$ heated to 60$70^{\circ} \mathrm{C}$. in its hot condition, in hot condition, the solution is titrated with kalium permanganate $\left(\mathrm{KMnO}_{4}\right)$ 0,1 N x mL until stable pink colour appeared in the solution for 30 second

$$
1 / 2 \mathrm{~K}_{2} \mathrm{MnO}_{4(\mathrm{~s})}+1 / 2 \mathrm{MnO}_{2(\mathrm{~s})}+1 / 2 \mathrm{O}_{2(\mathrm{~g})} \longrightarrow \mathrm{KMnO}_{4(\mathrm{~s})}
$$


- $\quad \%$ yield calculation of oxalic acid:

$$
\% \text { Yield }=\frac{\text { Actual yield (gr) }}{\text { Raw material (gr) }} \times 100
$$

\section{Melting Point Test}

Put obtained oxalic acid crystal in the melting point apparatus, then turn it on and look for the temperature till it melt

\section{RESULTS AND DISCUSSION}

This study used temperature variables of $55,65,75$, and $95^{\circ} \mathrm{C}$, and time variables for $60,70,80$ and $90 \mathrm{~min}$.

\section{III.1 Effect of Removing Ink and Lignin on the Result of Oxalic Acid Crystals}

In the pre-treatment process, removing ink and lignin is carried out, which aims to remove lignin content so that cellulose remains and remove ink on HVS paper waste. In addition, removing ink and lignin can increase levels of the results of the oxalic acid by $20 \%$ with $\mathrm{p}$ e marinade Potassium Permanganate $\left(\mathrm{KMnO}_{4}\right)$, immersion in hydrogen peroxide $\left(\mathrm{H}_{2} \mathrm{O}_{2}\right)$, and washing using aquadest.

The percentage of $20 \%$ can be seen from the final result of oxalic acid. Here is a comparison of making oxalic acid without using removing ink and lignin, and our research using removing ink and lignin [6].

TABLE 2.

WEIGHT COMPARISON OF OXALIC ACID

\begin{tabular}{cccc}
\hline \hline No & $\begin{array}{c}\text { Variable } \\
\text { temperature } \\
\text { and time }\end{array}$ & $\begin{array}{c}\text { Research } \\
\text { by removing } \\
\text { ink and } \\
\text { lignin }(\mathrm{g})\end{array}$ & $\begin{array}{c}\text { Journal without re } \\
\text { moving ink and } \\
\text { lignin }(\mathrm{g})\end{array}$ \\
\hline 1. & $75^{\circ} \mathrm{C}$, & 1.3 & 1.1891 \\
2. & $60 \mathrm{~min}$ & & \\
$75^{\circ} \mathrm{C}$, & 1.4 & 0.8642 \\
3. & $70 \mathrm{~min}$ & 2.7 & 0.5357 \\
4. & $75^{\circ} \mathrm{C}$, & & 0.3313 \\
\hline \hline
\end{tabular}

From Table 2, the ratio of the weight of oxalic acid between the research by removing ink and lignin and journal without removing ink and lignin is obtained. The journal that we make comparison is entitled "Waktu dan Suhu Optimum dalam Produksi Asam Oksalat $\left(\mathrm{H}_{2} \mathrm{C}_{2} \mathrm{O}_{4}\right)$ dari Limbah HVS dengan Metode Peleburan Alkali” by Nurul year 2017. For the first variable, at a temperature of $75^{\circ} \mathrm{C}$ for $60 \mathrm{~min}$, the weight of oxalic acid was obtained as much as 1,3 $\mathrm{g}$ in the research, while in other papers, it only produced $1,1891 \mathrm{~g}$. For the second variable, at a temperature of $75^{\circ} \mathrm{C}$ for $70 \mathrm{~min}$, the mass of oxalic acid was obtained as much as $1,4 \mathrm{~g}$ in the research, while in other papers, it only produced $0,8642 \mathrm{~g}$. For the third variable, at a temperature of $75^{\circ} \mathrm{C}$ for $80 \mathrm{~min}$, a mass of $2,7 \mathrm{~g}$ of oxalic acid was gained in the research, while other papers only produced $0,5357 \mathrm{~g}$.
For the fourth variable, at a temperature of $75^{\circ} \mathrm{C}$ for 90 min, the mass of oxalic acid was obtained as much as 2,3 $\mathrm{g}$ in the research while in other papers it only produced $0,3313 \mathrm{~g}$.

So it can be concluded that, by carrying out the pretreatment process using removing ink and lignin , it is very influential on increasing the final yield of oxalic acid.

\section{III.2 Effect of Surface Area of HVS Paper Waste on Pre-Treatment for Hydrolysis Process}

Hydrolysis is the breakdown of salt in water which produces acid or base. One factor that affects the hydrolysis process is the size of the raw material or surface area of HVS Paper Waste. The small size of the raw material will cause the contact area between the raw material and the cooking solution to be wider, so that the reaction is more perfect, and vice versa. The size of the raw material that is too small will cause the capture point of the forces that hit the resulting pulp to be smaller, so that the pulp cannot withstand these forces and the resulting paper will tear easily. The surface area of HVS paper waste in this study used a ratio of $14,8 \mathrm{~cm} \times 21 \mathrm{~cm}$ and 0,5 $\mathrm{cm} \times 0,5 \mathrm{~cm}$. From this comparison, it can be concluded that with a surface area of $14,8 \mathrm{~cm} \times 21 \mathrm{~cm}$ HVS paper waste makes it easier to remove ink and lignin so that the reaction is more complete in the hydrolysis process [8].

In this research, medium size HVS paper waste is used for optimal hydrolysis results in the pre-treatment process.

\section{III.3 Effect of Time and Temperature on Oxalic Acid Mass}

The manufacture of oxalic acid was carried out with variations in the time used in this study, namely $60,70,80$ and $90 \mathrm{~min}$ while the temperature variations used were $55^{\circ} \mathrm{C}, 65^{\circ} \mathrm{C}, 75^{\circ} \mathrm{C}$ and $95^{\circ} \mathrm{C}$.

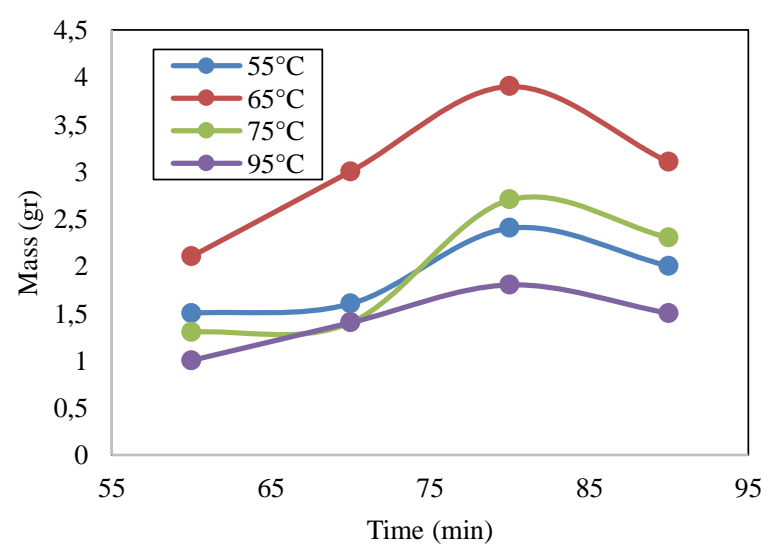

Figure 1. Effect of Time and Temperature to the Mass of Oxalic Acid

Based on Figure 1, the time and temperature for producing oxalic acid from the Figure can be seen that the average temperature that produces the most oxalic acid is at $80 \mathrm{~min}$ and a temperature of $65^{\circ} \mathrm{C}$, which is $3,9 \mathrm{~g}$. 
In the hydrolysis process, lignocellulose in paper can be broken down into lignin, cellulose and hemicellulose using a $40 \%$ sodium hydroxide $(\mathrm{NaOH})$ solution where the alkaline solution $(\mathrm{NaOH})$ in the hydrolysis process functions to break down molecules so that it is easier to attract the cellulose contained in the paper. Cellulose is a carbohydrate that is used as an ingredient in the manufacture of oxalic acid, cellulose contained in paper as much as $85 \%$.

In hydrolysis of cellulose to produce glucose, it will produce oxalic acid with the addition of an acid solution. In the hydrolysis step with a strong base using a $40 \% \mathrm{NaOH}$ solution, sodium oxalate, sodium formate and sodium carbonate are formed in the form of a filtrate using temperatures of $55^{\circ} \mathrm{C}, 65^{\circ} \mathrm{C}, 75^{\circ} \mathrm{C}$ and $95^{\circ} \mathrm{C}$ according to the reaction of cellulose with $\mathrm{NaOH}$ solution. According to Narimo et al. [9], the separation of the salt can be done by precipitation and filtration by adding calcium chloride. The addition of calcium chloride $\left(\mathrm{CaCl}_{2}\right)$ is used to form a white precipitate of calcium oxalate, and sodium chloride separation is done by filtration. In the acidification step, the precipitate obtained is added with $4 \mathrm{~N}$ sulfuric acid so that it decomposes into a precipitate of calcium sulphate and a solution of oxalic acid according to the following reaction:

Oxalic acid crystals can be formed because the oxalic acid solution is in a supersaturated state or condition; this happens because the solvent is no longer able to dissolve the solute, forcing crystals to form by reducing the amount of solvent, one way to reduce the amount of solvent is evaporation and cooling.

Temperature affects the reaction speed, i.e., if the temperature is high, the reaction rate constant will be greater so that the reaction will also be more significant, but too high a temperature will break down oxalic acid, thereby reducing the yield [9]. An extended reaction time will produce a large amount of oxalic acid, but if the time used is too long, it will cause further reactions to reduce the results. This is in accordance with the research that temperature and time affect the yield of oxalic acid. Reaction time that is too high causes the yield of oxalic acid to decrease at $90 \mathrm{~min}$, while the optimum temperature in the manufacture of oxalic acid is at a temperature of $65^{\circ} \mathrm{C}$ and decreases at a temperature of $55^{\circ} \mathrm{C}, 75^{\circ} \mathrm{C}$ and $95^{\circ} \mathrm{C}$. So the mass of oxalic acid is the highest. It was obtained at $80 \mathrm{~min}$ with a temperature of $65^{\circ} \mathrm{C}$ that is equal to $3,9 \mathrm{~g}$.

\section{III.4 Effect of Time and Temperature on Oxalic Acid Yield}

The manufacture of oxalic acid was carried out with variations in the time used in this study, namely 60,70 , 80 and $90 \mathrm{~min}$ while the temperature variations used were $55^{\circ} \mathrm{C}, 65^{\circ} \mathrm{C}, 75^{\circ} \mathrm{C}$ and $95^{\circ} \mathrm{C}$. The $\%$ yield of oxalic acid is shown in the table following.

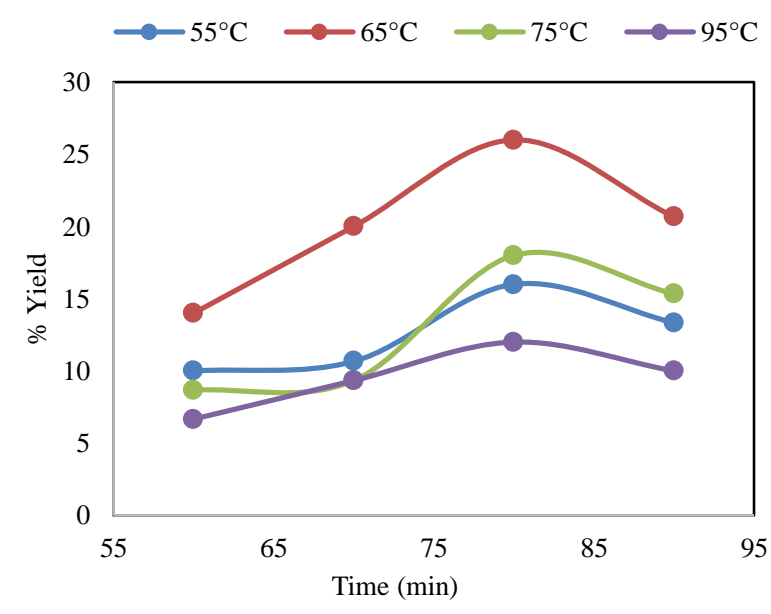

Figure 2. Effect of Time and Temperature on Oxalic Acid Yield

In Figure 2, it can be seen that the longer the melting time and temperature, the more $\%$ yield of oxalic acid produced, but too high a temperature will break down the oxalic acid, thereby reducing the yield of $\%$ oxalic acid. Therefore the reaction temperature must be limited.

Permanganometric titration uses $0.1 \mathrm{~N}$ potassium permanganate $\left(\mathrm{KMnO}_{4}\right)$ as the titrant and also acts as an indicator. Titration is done in an acidic state by using a solution of sulfuric acid $\left(\mathrm{H}_{2} \mathrm{SO}_{4}\right) 4 \mathrm{~N}$. Function addition of sulfuric acid so that the reaction is acidified so as $\mathrm{MnO}^{4-}$ to $\mathrm{Mn}^{2+}$. If the solution is neutral or slightly alkaline then $\mathrm{KMnO} 4$ will be reduced to $\mathrm{MnO} 2$ in the form of a brown precipitate, complicating the endpoint.

Heating is carried out because the reaction in permanganate is slow at room temperature. In this study, a temperature of $70{ }^{\circ} \mathrm{C}$ was used because that temperature is the optimum temperature for $\mathrm{KMnO}_{4}$. If the temperature is below $70^{\circ} \mathrm{C}$, then the reaction is slow, while if the temperature is above $70^{\circ} \mathrm{C}$, it will damage the oxalic acid so that the endpoint of the titration will be less. In this study, oxalic acid mixed with distilled water and sulfuric acid before titrating colored translucent and turned into red light after titration.

It is demonstrated that the crystals obtained positive oxalic acid, a color change indicates the endpoint or equivalence point titration. The color change caused is because the indicator responds to the appearance of excess titrant. Yield most established in $80 \mathrm{~min}$ at $65^{\circ} \mathrm{C}$ is equal to $26 \%$.

The crystals obtained were used as the starting point for purification. They were air dried and sampled and then dissolved in distilled water forming a saturated solution at $70^{\circ} \mathrm{C}$. This solution was divided into two parts and crystallized and drained exactly as described above. After sampling each portion the remainder was again dissolved in distilled water and crystallized exactly as it had been before. 
A figure can be made of the relationship between time and temperature to the concentration of oxalic acid as follows.

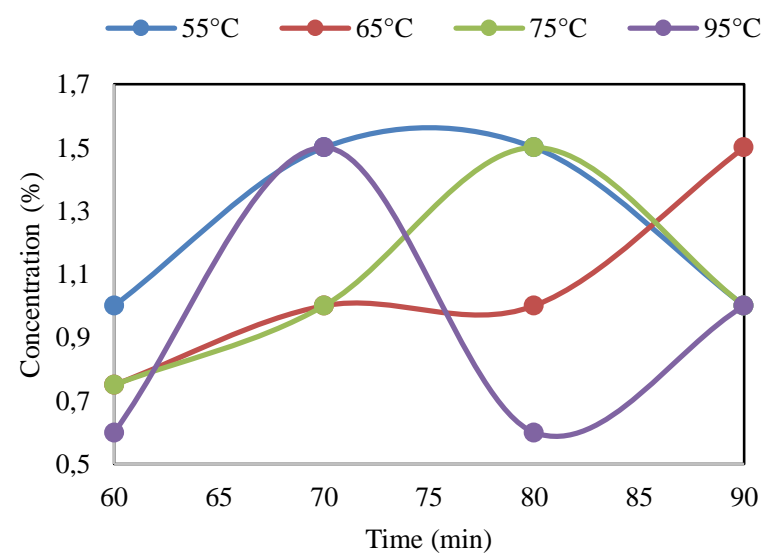

Figure 3. Effect of Time and Temperature on Oxalic Acid Concentration

Based on Figure 3, temperature affects the reaction speed. If the temperature is high, the reaction rate constant will be greater so that the reaction will be even more significant, but too high a temperature will decompose oxalic acid, thereby reducing the concentration of oxalic acid. Therefore the reaction temperature must be limited.

An extended reaction time will result in a high concentration of oxalic acid but if the time used is too long it will cause further reactions so that the results will decrease and the concentration of oxalic acid will decrease. This result is in accordance with the research that temperature and time affect the concentration of oxalic acid, namely at a temperature of $55^{\circ} \mathrm{C}$ for 70 and $80 \mathrm{~min}, 65^{\circ} \mathrm{C}$ for $90 \mathrm{~min} 75^{\circ} \mathrm{C}$ for $80 \mathrm{~min}, 95^{\circ} \mathrm{C}$ for $70 \mathrm{~min}$, the concentration of oxalic acid is $1,5 \%$ [8].

\section{III.5 Melting Point Test Analysis}

Test the melting point of oxalic acid crystals using a melting point apparatus. The results of the analysis show that the melting point obtained is between 100$101{ }^{\circ} \mathrm{C}$ this happens because the oxalic acid in the research indicates that the oxalic acid corresponds to the actual melting point of oxalic acid based on the Indonesian National Standard (SNI) which is 101$102{ }^{\circ} \mathrm{C}$.

\section{CONCLUSION}

The optimal time and temperature conditions in producing oxalic acid were at $80 \mathrm{~min}$ and $65^{\circ} \mathrm{C}$, which yielded $3.9 \mathrm{~g}$. The analysis results show that the melting point obtained is between $100-101^{\circ} \mathrm{C}$. It happens because the oxalic acid in the research indicates that the oxalic acid corresponds to the actual melting point of oxalic acid based on the Indonesian National Standard (SNI), namely 101$102^{\circ} \mathrm{C}$.

\section{REFERENCES}

[1] S. Wahyono, Jurnal Teknologi Lingkungan, Vols. 2, No. 3, pp. 276-280., September 2001.

[2] A. Poedjiadi and F. M. T. Supriyanti, "Dasar-Dasar Biokimia Edisi Revisi,” UI-Press. Jakarta, 2006.

[3] H. Taruna, A. Rita, S. Tania, and A. Sri, "Studi Awal Pemanfaatan Limbah Kertas HVS sebagai Bahan Baku Dalam Proses Pembuatan Etanol," Univ. Indones., 2010.

[4] M. Endang, "Pembuatan Asam Oksalat dari Sekam Padi," Ekuilibrium, vol. 4(1), pp. 13-17., 2005.

[5] A. F. Sitanggang and R. D. A. Pohan, "Pembuatan Asam Oksalat Dari Alang-Alang (Imperata Cylindrica) Dengan Metode Peleburan Alkali," J. Tek. Kim. USU, vol. 4, no. 1, pp. 16-19, 2015.

[6] A. S. Cushman, "Process for removing ink and other stains from cloth, paper, \&c." Google Patents, Dec. 14, 1920.

[7] L. Masruroh, F. Ramadhan, S. Firdiantama and B. A. Kindhi, "SIAB" Smart E-Stoichiometry as a Chemistry Learning Acid Base on Android Mobile," in AIP Conference Proceeding, 2021.

[8] K. Sumanda, "Kajian proses isolasi $\alpha$ - selulosa dari limbah batang tanaman manihot esculenta crantz yang efisien. UPN "Veteran" Jawa Timur, Surabaya.," 2011.

[9] Narimo, "Pembuatan Asam Oksalat dari Peleburan Kertas Koran Bekas dengan Larutan NaOH," Jurnal Fakultas Teknik Universitas Setia Budi, Surakarta, 2006. 